\title{
BOGDAN LESIŃSKI
}

\section{„Ius dispositivum” $w$ dawnych zobowiqzaniach polskich}

\author{
„Ius dispositivum” im altpolnischen Schuldrecht
}

1. Przykłady źródłowe z XV-XVII w., wskazujące, że w dawnym polskim (szlacheckim) prawie zobowiązań treść umów kształtowana była głównie przez samych kontrahentów. 2. Obejmowanie tym zwyczajem tak prawa procesowego (np. wyłączenie przez strony możliwości apelacji), jak i prawa materialnego (np. wyłączenie możliwości powoływania się na przedawnienie). 3. Dominacja zasady wolności umów - swobodnego kształtowania ich treści w stosunkach między członkami stanu szlacheckiego.

1. Rechtsquellen aus dem 15 . bis 17. Jahrhundert deuteten daraufhin, dass der Inhalt der Verträge im altpolnische adeligen Obligationsrecht hauptsächtlich von den Kontrahenten selbst gestaltet wurde. 2. Derartige Praxis bezog sich sowohl auf das Prozessrecht (so zum Beispiel zur Aussonderung der möglichen Appelation der Streitpartner) als auch auf das materielle Recht (so beispielsweise zur Ausschliessung einer möglichen Verjährung der Ansprüche). 3. Das Freiheitsprinzip der Verträge im Adelsstand, war dominierend.

1. Jaką moc miało w praktyce dawne polskie prawo ziemskie? Czy przeważały w nim normy bezwzględnie wiążące ius cogens, czy też w większości - przynajmniej w niektórych dzialach prawa prywatnego - dominowały normy względnie wiążące (czyli ius dispositivum)? Do zajęcia się tym problemem w niniejszym artykule inspiracją stały się uwagi Jacka S. Matuszewskiego, który w pracy o zastawie polskim, stwierdzając praktykę wyłączania dawności (przedawnienia) w drodze umowy przez zainteresowane strony, skonstatował, że: ...uznawano prawo stron do dowolnego regulowania wzajemnych praw i obowiazków wynikajqcych z zawieranego kontraktu; dawność statutowa to ius dispositivum a nie ius cogens, przynajmniej dla stosunków zastawnych.

Opierając się na tej obserwacji J. S. Matuszewskiego oraz własnych przemyśleniach, autor niniejszych uwag także podkreślał, że dawne prawo polskie w dużej mierze było ius dispositivum ${ }^{2}$.

'J. S. Matuszewski, Zastaw nieruchomości w polskim prawie ziemskim do konca $X V$ stulecia, Zesz. Nauk. Ut 1979, S. I, nr 53, s. 159-160.

${ }^{2}$ E. Bagieńska-B orkowska, B. Lesiński, Historia prawa sqdowego, Poznań 1995, s. 130, także w artykule Dilatio propter minorennitatem $w$ dawnym polskim procesie ziemskim, 
Dysponujemy bowiem źródłami, według których można było w drodze umowy wyłączać nie tylko ,dawność”, lecz także inne instytucje czy działania prawne funkcjonujące $w$ dawnym prawie polskim, w szczególności w dawnych zobowiazzaniach. Wzmianek tego typu jest bezlik. W samym tylko wydawnictwie źródłowym Janusza Deresiewicza dotyczącym transakcji chłopami ${ }^{3}$ jest ich blisko setka. Poniżej podajemy kilka tekstów pochodzących z XV-XVII w., zawierających umowne klauzule dotyczące wspomnianych wyłączeń.

I. (SPPP II, nr 270, s. $430-1437$ r.) $)^{4}$. Poręczenie złożone przez różnych dostojników za kilku braci z Rytwian, że ci wydadzą połowę wszystkich dóbr przez nich dzierżonych Mikołajowi Borzysławskiemu, gdy ten osiągnie pelnoletność (tj. ukończy 15 lat). Poręczyciele stwierdzają m. in.: ...promittentes quovis iure non evadendo, spirituali aut seculari litteris aut mandates regalibus, expedicione vadio, aut quibusvis articulis, qui nobis prodessent et ipsi Nicolao Borzyslowski obessent. Promittimus eciam non evadere diuturnitate terrestri, alias nie odbijaćt ziemskq dawnościq, nec aliquid pro auxilio recipere, quo possemus evadere predictam caucionem fideiussoriam, sed satisfacere et fideiubemus, et personis nostris propriis coram iudicio obmittimus diuturnitatem terrestrem, alias dawność ziemska.

II. (AGZ XII - halickie, $n r$ 2969/1460 r. $)^{6}$. Stanisław z Chotecza zobowiązany jest zapłacić na święta Bożego Narodzenia Zbrosławowi z Goli 50 grzywien i 8 wiardunków tytułem zwrotu pożyczki.

Et non Sbroslaum evadere debet nec mandatis regis, nec colloquio generali, nec convencionibus generalibus neque particularibusque aliquo laudo antiquo, moderno et futuro, nec pro maiori, neque prescripcione nec diuturnitate aliqua nec prorogacione terminorum neque guerris Thartharorum neque inundacione aquarum neque aliqua captivitate nec simplici neque vera infirmitate nec aliquo modo disposito aut excogitato, nec literis pergamineis neque papireis, tum regis aut consilii aut aliquorum, iudicum aut suorum amicorum.

III. (D e resiewicz, Transakcje, nr 251, s. 223 - kaliskie, 1568 r.) ${ }^{7}$. Andrzej Karski zobowiązuje się wzdać swych dwóch poddanych z mieniem Dobrogostowi Potworowskiemu. Jeżeli nie wywiąże się ze swego zobowiązania, to: ... in primo citacionis termino tanquam peremptorio debet et tenebitur, vel eius successores tenebuntur, stare, parere, respondere et pro citatis omnibus

[w:] Parlamentaryzm i prawodawstwo przez wieki. Prace dedykowane Prof. Stanislawowi Plazie $w$ siedemdziesiqtq rocznice urodzin, red. J. Malec, W. Uruszczak, Kraków 1999, s. 321-322.

${ }^{3}$ J. Deresiewicz [wybrał i do druku przygotował], Transakcje chlopami w Rzeczypospolitej szlacheckiej w. XVI-XVIII, Warszawa 1959.

${ }^{4}$ SPPP II - Starodawne prawa polskiego pomniki, t. II.

5 W tekście Helcla jest: odbywać (odbiwacz).

'AGZ - Akta grodzkie i ziemskie.

Deresiewicz, Transakcje - patrz przyp. 3. 
a iudicio vel officio, dum causae officii iudicabantur, non recedendo toties quoties opus fuerit, satisfacere ac decretum iudicii sive officii totumque iuris progressum usque ad finalem executionem pati, ipsum primum terminum peremptorium et omnia praemissa, nullis diffugiis, dilationibus, exceptionibus, appelationibus, motionibus ad prosequendum motionem sive appelationem, adcitationibus, inhibitionibus, actione pro maiori, convencione generali aut particulari, bello, litteris regalibus, vera vel simplici infirmitate, successorum minorennitate, statutis laudatis et in futurum laudandis, diverticulis et coloribus iuris quibusque quaesitis, excogitatis, poenisque de iure vel consuetudine fieri solitis, evadendo, nihilque penitus sibi in auxilium contra praesentem inscriptionem et ex ea emanatam citationem totumque processum assumendo sub suae totius et integre causae amissione [...] nulla diuturnita et praescriptione terrestri in praemissis obstante.

IV. (D e resiewicz, Transakcje, nr 395, s. 355 - pyzdrskie, 1633 r.). Jan Goltowski przyrzeka, że udzieli zastępu Esterze Wilkońskiej, wydającej mu pasterza $z$ rodziną $i$ mieniem, $w$ razie ewentualnych roszczeń Lukasza Piglowskiego. W razie niespełnienia przyrzeczenia zobowiązany jest stanąć przed sądem $\mathrm{w}$ pierwszym terminie zawitym i: ...omnia praemissa nullis difugiis, dilationibus, exceptionibus, tam contra presentem inscriptionem, quam etiam processum iuris, quasi male obtentum esset, inferendo, motionibus appelationibus ad prosequendum easdem adcitationibus, inhibitionibus, evasionibus, interregno, actione pro maiori, conventu Regni generali sive particulari, bello, litteris regalibus, absentia a Regno, vera vel simplici infirmitate, successorum minorennitate, statutis laudatis et in futurum quomodolibet laudandis, aura pestifera, poena trium et ter trium marcarum pecuniarum, diverticulis et coloribus iuris quibusvis quaesitis, exquirendis, excogitatis, evadendo neque ad quietationem ulteriorem dilationem alibi praeter ad acta praesentia, tum ad evictorem seu intercessorum sibi recipiendo, nullosque defectus presenti inscriptioni et ex ea emanatae citacioni obiiciendo ac penitus nihil iuris remediorum contra praemissa in auxilium sibi assumendo [...] quibus omnibus praemissis se benevole [...] Goltowski se submisit [...] nulla [...] praescriptione terrestri obstante...

Porządkujemy material zawarty w przytoczonych wyżej źródłach, by zorientować się, do czego zobowiązywał się dłużnik w razie procesu. Otóż jeśli doszło do sporu, dhużnik, stosownie do klauzul umownych wyłączających środki, które normalnie powinny mu przyshugiwać, winien stanąć na pierwszym, zawitym roku i bezwzględnie wykonać zobowiązanie, nie próbując szukać jakichś przyczyn odroczenia procesu i nie stosując uników (nullis diffugiis evadendo - III, IV), by odeprzeć roszczenia wierzyciela.

Taka ogólna formula występuje niemal we wszystkich przytoczonych tekstach. Mówi się np., że dhużnicy-poręczyciele (I) nie będą postępowali tak, aby odnieść korzyść, a zaszkodzić wierzycielowi, czy też że dłużnik nie będzie podejmował działań przeciwko umowie i procesowi, pod groźbą 
przegrania sprawy (III. ...nihil penitus sibi in auxilium contra praesentem inscriptionem et ex ea emanatam citacionem totumque processum assumendo sub suae totius et integre causae amissione).

2. Takie klauzule generalne nie zastępowały jednak (przynajmniej do XVII w.) szczegółowych wyłączeń działań, mogących normalnie powodować odroczenie procesu czy przegranie przez wierzyciela sprawy. Wymienia sie je bowiem jednocześnie $\mathrm{z}$ generalnymi. Właśnie te szczegółowe wyłączenia są istotne ze względu na interesującą nas kwestię mocy obowiązującej dawnego prawa polskiego. Układamy je niżej w kilka grup.

- Wyłączenia dylacji procesowych ${ }^{8}$ stosowanych ze wzgledu na następujące przyczyny: a. powódź (II); b. zaraza (IV); c. niewola jeniecka (II); d. wojna i wyprawa wojenna (I, III, IV); e. nieobecność w Królestwie (IV); f. bezkrólewie (IV) ${ }^{9}$; g. lekka lub ciężka choroba (II, III, IV); h. równoczesny spór "o większe" (pro maiori - II, III, IV); i. inhibicje, mandaty i w ogóle pisma królewskie, nakazujące odłożenie terminu rozprawy (I, II, III, IV); $\mathbf{j}$. udział w zjazdach szlachty, wiecach, sejmikach i sejmie (II, III, IV); k. małoletnośćc ${ }^{10}$.

- Wyłączenie możliwości zastosowania w procesie ekscepcji i przypozwań (adcitationes - III, IV). W zakresie ekscepcji znamienny jest zakaz posłużenia się ewikcją (zastępem - IV) oraz argumentem, że przedmiot świadczenia jest zastawiony (I) ${ }^{11}$.

- Wyłączenie zastępczego (zamiast wykonania świadczenia) zapłacenia kar umownych (wadium - I) oraz ustalonych przez prawo (3 grzywny lub trzykroć tej sumy - III, IV).

- Wylączenie możliwości stosowania przez dhużnika środków prawnych, takich jak apelacja, mocja i male obtentum (III, IV).

Wyłączenie stosowania przedawnienia (diuturnitas, praescriptio terrestris) roszczeń wierzyciela (I, II, III, IV).

Wyłączenie możliwości powoływania się przez dłużnika na przepisy prawa tak dawnego, współcześnie obowiązującego, jak i przyszlego, uchwalonego przez wiece, sejmiki i sejm (II, III, IV) w postaci laudów i statutów.

${ }^{8}$ O umownym wyłączaniu dylacji przez strony wspominaja: J. R a f a c z, Dawny proces polski, Warszawa 1925, s. 141; Z. W a chlowski, Dylacje procesowe w sqdownictwie ziemi ruskiej $X V$ i XVI wieku, Pam. Hist.-Prawny [Lwów] 1926, t. III, z. 3, s. 19-21; S. Kutrze ba, Dawne polskie prawo sqdowe w zarysie, wyd. 2, Lwów 1927, s. 85; J. B a rdach, Historia państwa $i$ prawa Polski, t. I, wyd. 2, Warszawa 1964, s. 538.

9 W literaturze naukowej nie ma wzmianki o istnieniu takiej dylacji.

${ }^{10} \mathrm{Z}$. W a chlowski, Dylacje procesowe..., s. 24, twierdził, że zrzeczenie sie dobrowolne [tej dylacji - sc. z przyczyny małoletniości - B. L.] bylo niedopuszczalne. Wachlowski oparł swą rozprawę na materiale $w$ AGZ, tymczasem $w$ aktach tych znajdujemy zapiski stwierdzające wyłączenia dylacji z powodu małoletniości (AGZ XVI, nr 1851/1483 r., 2983/1498 r.; AGZ XVIII, 2483/1495 r., 2638/1498 r.).

1) Tak rozumiem wyraz obligacione. 
3. Okazuje się więc, że cytowane wyżej teksty źródłowe zawierają szeroką gamę umownych wyłączeń posługiwania się prawem normalnie obowiązującym. Klauzule tego typu, tj. bardziej rozbudowane, występują co najmniej do połowy XVII w. ${ }^{12}$ Mniej więcej od połowy XVII w. pojawiają się już klauzule skrócone lub niemal całkowicie uproszczone, obejmujące tylko zastrzeżenie, że dhuznik wykona świadczenie bez jakiegokolwiek sprzeciwu i bez względu na przedawnienie (contradictione quavis ac prescriptione terrestri in praemissis minime obstante $)^{13}$. Nie wiemy jednak, czy zastrzeżenie contradictione quavis było równoznaczne $\mathrm{z}$ tym, co podawały cytowane przez nas wyżej rozbudowane klauzule. Tylko te ostatnie dają - jak wspomniano - podstawę do rozważań na temat ius dispositivum w dawnych zobowiązaniach.

Trudno jest odnaleźć bezpośrednio w naszym dawnym prawie stanowionym przepisy zawierające normy względnie wiążące ${ }^{14}$. Niewątpliwie takie istniały ${ }^{15}$; trzeba by jednak przejrzeć całość dawnego (skąpego zresztą) ustawodawstwa, by stwierdzić, w jakich rozmiarach one występowały. Pamiętajmy jednak, że nasze prawo było oparte przede wszystkim na zwyczaju i praktyce, i że było ono niemal nie spisane. Odtworzenie w tym wypadku obowiązujących norm następuje na podstawie źródeł praktyki prawnej. Jeżeli więc odkrywamy normy iuris dispositivi, to przede wszystkim za pomocą domniemania polegającego na tym, że jeśli znajdujemy umowne wyłączenie przez strony znanej $^{16}$ (najczęściej jednak nie znanej) normy prawnej, to domyślamy się, że owo wyłączenie było rezultatem tego, iz norma ta była względnie wiążąca.

Jeżeli przyjrzymy się cytowanym przez nas źródłom $\mathrm{z}$ podanego wyżej punktu widzenia, to stwierdzimy, że ius dispositivum miało szerokie zastosowanie $w$ dawnym polskim prawie zobowiązań. Nie dziwią specjalnie ograniczenia czysto procesowe dotyczące zobowiązań, takie jak umowne wyłączenia stosowania dylacji, ekscepcji i przypozwań (adcitationes) oraz

12 Ostatnia nam znana, tj. najmłodsza, pochodzi z 1650 r., z powiatu nakielskiego, J. De resiewicz, Transakcje..., nr 726 (s. 656).

${ }^{13}$ Ibidem, nr 108 (kościańskie, 1690 r.); por. także nr nr 107 i 109 do 111.

14 Przypomnijmy, że współczesna cywilistyka rozumie przez nie te normy, które dają możliwość ich niestosowania, jeżeli strony stosunku cywilnoprawnego postanowią inaczej niż stwierdzają to normy, czy też gdy pierwszeństwo daje się zwyczajowi decydującemu o ich niestosowaniu, por. Z. Radwański, Prawo cywilne - część ogólna, 3 wyd., Warszawa 1997, s. 44-45.

${ }^{15}$ Przykładem ich może być norma zawarta w art. 324 nie przyjętej Korektury Praw z 1532 r. stwierdzająca, że pretensje wierzyciela z tytułu pożyczki przedawniają siẹ po 4 latach, jednak strony mogły przedłużyć okres dawności, bądź dłużnik mógł się zrzec prawa skorzystania $z$ przedawnienia (nisi inter partes de longiori solutionis tempore conventum esse, vel debitor praescriptioni expresse renuntiasset); por. W. U r u z c zak, Korektura Praw z 1532 r., t. I, Kraków-Warszawa 1990, s. 241.

${ }^{16}$ Do takich znanych norm prawa zwyczajowego należały $m$. in. te, które odnotowano w Najstarszym Zwodzie (por. J. B a r d a ch, Historia państwa..., s. 346), a dotyczyly dylacji z przyczyny choroby, uwięzienia i służby książęcej art. 4, p. 6), później generalnie (por. III, IV) lub indywidualnie wyłączanych przez strony w umowach. 
niedopuszczalność odłożenia procesu przez uiszczenie odpowiedniej kary. Wynikały one $\mathrm{w}$ dużej mierze $\mathrm{z}$ silnie osadzonej $\mathrm{w}$ dawnym procesie polskim zasady dyspozytywności ${ }^{17}$.

Inne postanowienia $\mathrm{w}$ klauzulach umownych dotyczących postępowania dłużnika budzą jednak zdumienie wspólczesnego prawnika. Mamy tu na myśli umowne wyłączenia dawności, jak i moźliwości korzystania ze środków prawnych (apelacja $\mathrm{i}$ inne) oraz powolywania się na przepisy prawa.

Co do dawności, to wszystkie cytowane wyżej teksty źródłowe wspominają o wyłączeniu nieodpowiedzialności dłużnika $\mathrm{z}$ powodu przedawnienia. Wydaje się, że było ono niemal powszechnie praktykowane; do takiego wniosku dojdzie każdy badacz czytający XV-, XVI- i XVII-wieczne dokumenty. Stwierdzi on, że roi się $w$ nich od wylączeń dawności i to nie tylko w zakresie zobowiązań, lecz także prawa rzeczowego (zastaw) ${ }^{18}$. Przedawnienie roszczeń traktowano więc zupełnie inaczej niż dzisiaj. Współczesne prawo uznaje bowiem przedawnienie za instytucje iuris cogentis, której nie moźna wyłączyć ani ograniczyć wolą stron czy odmiennym zwyczajem ${ }^{19}$.

Klauzule umowne zawierają też wyłączenia możliwości skorzystania przez dłużnika $\mathrm{z}$ apelacji $\mathrm{i}$ innych środków prawnych, $\mathrm{w}$ razie przegrania sprawy w sądzie pierwszej instancji. Oznaczało to obezwładnienie dłużnika przez pozbawienie możliwości obrony w wyższej instancji. Obecne prawo uznałoby taką umowę za bezskuteczną.

Jak daleko strony zgadzały się na swobodne kształtowanie treści umowy, świadczy zastrzeżenie dzisiaj wydające się nieprawdopodobne i nieco karykaturalne - że dłużnik nie będzie dla obrony swych uprawnień wykorzystywał przepisów prawa dawnego, wspólczesnego i przyszlego. Taka formuła wyłączała w ogóle zastosowanie obowiązującego prawa, które dla stron było tylko ius dispositivum, ale w wypaczonym sensie, a mianowicie takim, że umawiające się strony $w$ ogóle nie musiały się trzymać prawa - tzn. ani z zakresu ius cogens, ani też ius dispositivum w takim znaczeniu, jakie dzisiaj tym normom przypisujemy.

Dawne, polskie (ziemskie) zobowiązania jawią się więc nam $w$ świetle przytoczonych źródeł jako kształtowane przede wszystkim przez kontraktujące strony. One bowiem decydowaly o najbardziej istotnym elemencie umów, tj. treści stosunku cywilnoprawnego zwanego zobowiązaniem. Jeżeli postanowienia kontraktowe, którymi wyżej zajmowaliśmy się, były istotnie

\footnotetext{
${ }^{17}$ Por. S. Kutrzeba, Dawne polskie prawo..., s. 66; J. R a facz, Dawne prawo sqdowe $w$ zarysie, Warszawa 1936; J. B a rd a ch, Historia państwa..., s. 538.

${ }^{18} \mathrm{Na}$ powszechność umownych klauzul wyłączających przedawnienie przy zastawie już w XIV i XV w. wskazuja: Z. R y m a s ze ws k i, Zastaw w siwietle praktyki sqdow malopolskich $w X V$ wieku, Zesz. Nauk. UL 1962, S. I, nr 26, s. 130 (na podstawie zapisek małopolskich), oraz J. S. M a tuszew k i, Zastaw nieruchomości..., s. 153-159.

19 Z. R adwański, Prawo cywilne..., s. 44. Art. 119 naszego KC stwierdza, że: terminy przedawnienia nie mogq być skracane ani przedlużane przez czynność prawnq.
} 
przestrzegane $^{20}$, to można twierdzić, że w systemie dawnych zobowiązań w prawie ziemskim działała zasada swobody umów, wcale nie tak daleka - jak się sądzi ${ }^{21}$ - od tej, którą upowszechni słynny artykuł postanawiający, że umowy legalnie zawarte staja sie prawem dla tych, którzy je zawarli (art. 1134 Kodeksu Napoleona z 1804 r.).

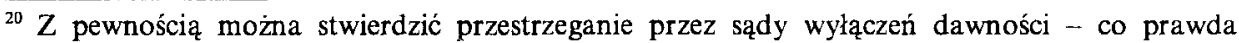
przy zastawach (por. J. S. M a tu s ze w ski, Zastaw nieruchomości..., s. 153-154); zapewne więc było podobnie przy sprawach dotyczących zobowiązań. Mało też prawdopodobne, by tak liczne, umowne klauzule wyłączające nie miały znaczenia dla stron, skoro wpisywano je (a więc utrwalano) do ksiąg sądowych. Przyznajemy jednak, że nie przeprowadziliśmy specjalnej kwerendy dotyczącej tego problemu.

${ }^{21}$ W. Uruszczak, Korektura..., s. 214, analizując tekst Korektury Praw z 1532 r., stwierdza, że pomijając umowy wyraźnie zabronione przez prawo, istniala zasadniczo swoboda umów. $\mathrm{Na}$ tej samej jednak stronicy pisze, że system kontraktowy w Korekturze nie znal oczywiście zasady wolności umów w znaczeniu, nadanym jej póżniej przez Kodeks Napoleona. Powstaje wątpliwość, czy w ogóle można mówić o różnych typach lub znaczeniach wspomnianej zasady, skoro wiemy, że zasada swobody umów polega właśnie na tym, że jest wyrazem autonomii woli umawiających się stron, a więc na tym, co tak dobitnie wyraził Kodeks Napoleona. 
